\title{
PENERAPAN METODE AHP SEBAGAI PENDUKUNG KEPUTUSAN PENETAPAN BEASISWA
}

\author{
Frieyadie \\ Program Studi Manajemen Informatika \\ AMIK BSI Jakarta \\ Jl. RS. Fatmawati No. 24 Pondok Labu Jakarta Selatan \\ frieyadie@bsi.ac.id
}

\begin{abstract}
Schools usually sets the rules or criteria that must be met by the applicants for the scholarship. The problems faced by the school in the process of determining the establishment of scholarships including data collection process is conventionally frequent errors and the absence of clear criteria for students to receive a scholarship and is having trouble because of the scholarship applicants and the number of criteria used to determine the decision of recipients. The research objective to avoid errors in data collection, and better process again what if you have a lot of criteria, so as to obtain the results expected by the selectors scholarship. AHP calculation results, obtained priority criterion in the assessment of the Scholarship Selection. Where Achievement, Non Academic Achievement, Income Parents, and Personality become a benchmark in the selection of the scholarship. The final results obtained from the selection of the scholarship by five experts that Student B is superior to 0.221 (22.1\%) while the Student A 0.213 (21.3\%), Student E 0.207 (20.7\%), Student D $0.182(18,2 \%)$ and the Student C 0.176 (17.6\%).
\end{abstract}

Intisari - Sekolah biasanya menetapkan aturanaturan atau kriteria-kriteria yang harus dipenuhi oleh calon penerima beasiswa untuk mendapatkan beasiswa tersebut. Permasalahan yang dihadapi oleh pihak sekolah pada proses penentuan penetapan beasiswa diantaranya proses pengumpulan data secara konvensional sering terjadi kesalahan dan tidak adanya kriteria yang jelas untuk siswa yang dapat memperoleh beasiswa dan mengalami kesulitan karena banyaknya pelamar beasiswa dan banyaknya kriteria yang digunakan untuk menentukan keputusan penerima beasiswa. Tujuan penelitian untuk tidak terjadi kesalahan dalam pengumpulan data, dan proses yang lebih baik lagi apa bila memiliki banyak kriteria, sehingga memperoleh hasil yang diharapkan oleh para penyeleksi beasiswa. Hasil perhitungan AHP, diperoleh prioritas kriteria dalam penilaian terhadap Pemilihan Beasiswa. Dimana Prestasi Akademik, Prestasi Non Akademik, Penghasilan Orang Tua, dan Kepribadian menjadi tolak ukur dalam melakukan pemilihan beasiswa. Hasil akhir yang didapat dari pemilihan beasiswa oleh lima orang ahli bahwa Siswa B lebih unggul $0,221(22,1 \%)$ sedangkan Siswa A 0,213 (21,3\%), Siswa E $0,207(20,7 \%)$, Siswa D 0,182 $(18,2 \%)$ dan Siswa C 0,176 (17,6\%).

Kata Kunci: AHP, Beasiswa, Penunjang Keputusan

\section{PENDAHULUAN}

Hampir setiap lembaga pendidikan khususnya sekolah banyak sekali beasiswa yang ditawarkan kepada siswa yang berprestasi maupun yang tidak mampu. Beasiswa bisa didapat berasal dari pihak sekolah dan dari luar sekolah. Sekolah biasanya menetapkan aturanaturan atau kriteria-kriteria yang harus dipenuhi oleh calon penerima beasiswa untuk mendapatkan beasiswa tersebut. Kriteria-kriteria yang ditetapkan adalah prestasi akademik, prestasi non akademik, penghasilan orang tua, dan kepribadian. Oleh sebab itu, tidak semua calon penerima beasiswa yang mengajukan beasiswa akan mendapakan beasiswa. Permasalahan yang dihadapi oleh pihak sekolah pada proses penentuan penetapan beasiswa diantaranya proses pengumpulan data secara konvensional sering terjadi kesalahan dan tidak adanya kriteria yang jelas untuk siswa yang dapat memperoleh beasiswa (Yulianti \& Damayanti, 2015). Dalam melakukan seleksi beasiswa tersebut tentu akan mengalami kesulitan karena banyaknya pelamar beasiswa dan banyaknya kriteria yang digunakan untuk menentukan keputusan penerima beasiswa yang sesuai dengan yang diharapkan. (Rizal, 2013),

Penelitian ini bertujuan untuk tidak terjadi kesalahan dalam pengumpulan data, dan proses yang lebih baik lagi apa bila memiliki banyak kriteria, sehingga memperoleh hasil yang diharapkan oleh para penyeleksi beasiswa.

\section{BAHAN DAN METODE}

\section{A. Teknik Pengumpulan Data}

Metode pengumpulan data yang dilakukan penelititerbagi menjadi 2 cara. Cara pertama 
dengan cara observasi langsung, Wawancara, Kuisioner untuk mendapakan data primer. Sedangkan untuk data sekunder berasal dari mengumpulkan dan mengidentifikasi serta mengelolah data tertulis berbentuk buku-buku yang berkaitan dengan penelitian.

\section{B. Populasi dan Sampel Penelitian}

Dalam melakukan penelitian ini, teknik pengambilan sampel dilakukan dengan cara nonprobability sampling dan pengambilan sampel dilakukan dengan cara purposive sampling. Populasi diambil dari unsur pimpinan sekolah dan Guru sebanyak 5 orang akan dijadikan sampel penelitian.

Tabel 1. Data Responden

\begin{tabular}{llc}
\hline No & Jabatan & Jumlah \\
\hline 1 & Kepala Sekolah & 1 \\
\hline 2 & $\begin{array}{l}\text { Wakil KepSek } \\
\text { Kurikulum }\end{array}$ & Bidang \\
& Guru BP & 1 \\
\hline 3 & Wali Kelas 1 & 1 \\
\hline 4 & Wali Kelas 2 & 1 \\
\hline 5 & Sumber: Hasil obeservasi (2016)
\end{tabular}

\section{Model Analisa Data}

Analisa merupakan bagian terpenting dalam metodologi penelitian ilmiah, dikarenakan dengan melakukan analisis, data tersebut dapat diberi arti dan makna yang berguna dalam suatu penyelesaian masalah. Metode AHP merupakan metode pengambilan keputusan yang komprehensif. Metode ini memperhitungkan halhal kualitatif (dari presepsi manusia) dan kuantitatif ( perhitungan metemeatika sesuai dengan formula atau rumus AHP ) sekaligus.

Metode pemecahan masalah yang gunakan dalam penelitian ini, yaitu AHP. Alasan pemilihan metode AHP karena AHP mampu digunakan untuk semua proses pemilihan sedangkan penentuan kriteria bisa di rubah sesuai dengan kepentingan konsumen. (Supriyono). Kelebihankelebihan analisis menggunakan AHP adalah: Kesatuan (Unity), Kompleksitas (Complexity), Saling ketergantungan (Inter Dependence), Struktur Hirarki (Hierarchy Structuring), Pengukuran (Measurement), Konsistensi (Consistency), Sintesis (Synthesis), Trade Off, Penilaian dan Konsensus Uudgement and Consensus), Pengulangan Proses (Process Repetition). AHP mampu membuat orang menyaring definisi dari suatu permasalahan dan mengembangkan penilaian serta pengertian mereka melalui proses pengulangan.

\section{Kajian Literatur}

Penelitian yang dilakukan oleh Kirom, Bilfaqih, \& Effendie (2012), mengemukanan pengamatan terhadap petugas seleksi beasiswa membandingkan informasi antar pelamar beasiswa secara manual. Setelah terpilih, maka data mahasiswa terpilih dipisahkan dan ditaruh dalam database beasiswa khusus. Secara umum, proses seleksi beasiswa yang sudah dilaksanakan tersebut kurang efektif dan kurang valid untuk menentukan penerima beasiswa. Metode AHP dipilih karena merupakan suatu bentuk model pendukung keputusan dimana peralatan utamanya adalah sebuah hierarki fungsional dengan input utamanya persepsi manusia, yakni dalam hal ini adalah orang yang ahli dalam masalah beasiswa atau orang yang mengerti permasalahan beasiswa. Hasil pengujian Simba ITS berbasis Sistem Pendukung Keputusan menggunakan metode AHP, dapat diambil kesimpulan bahwa sistem ini mampu memberikan pertimbangan kepada pengelola beasiswa ITS untuk menentukan prioritas terpilih dari seleksi beasiswa tertentu berdasarkan persepsi pengambil kebijakan tentang pengaruh kriteria tertentu. Selain itu, sistem ini dapat mempermudah pengelola beasiswa dan mahasiswa ITS dalam proses pendaftaran dan penginformasian beasiswa di ITS. Hardi
mengemukakan

permasalahan penentuan penerimaan beasiswa sering menjadi kendala dalam penyalurannya dan tidak terarah pada tujuan sebagaimana yang diharapkan, dimana penyelesaian tersebut sering diselesaikan menggunakan sistem pendukung keputusan. Untuk memberikan suatu perubahan yang baik dan terarah pada tujuan, khususnya dalam penentuan penerimaan beasiswa, diharapkan mampu memberikan suatu hasil yang baik dan lebih efisien melalui sistem pendukung keputusan. Pemecahan masalah dengan menggunakan metode fuzzy AHP. Proses kerja AHP akan melakukan perankingan yaitu melalui penjumlahan antara vector bobot dengan matrik keputusan dengan tujuan agar hasil yang diberikan lebih baik dalam menentukan alternative yang akan dipilih, sebagaimana output dari hasil perankingan

\section{HASIL DAN PEMBAHASAN}

\section{A. Struktur Analytical Hierarchy Process}

Setelah mendefinisikan permasalahan atau persoalan, maka dilakukan dekomposisi yaitu: memecah persoalan yang utuh menjadi unsurunsurnya. Dilakukan hingga tidak memungkinkan pemecahan lebih lanjut. Oleh karena itu, proses analisis ini dinamakan hirarki. Struktur hirarki pada skripsi ini terdiri dari goal, kriteria dan alternatif. Goal atau tujuan pada hirarki ini adalah sistem pendukung keputusan pemilihan beasiswa, sedangkan kriterianya adalah prestasi 
akademik, prestasi non akademik, penghasilan orang tua, kepribadian. Dan alternatif terdiri dari siswa A, siswa B, siswa C, siswa D, siswa E. Kriteria dan alternatif tersebut didapat dari hasil wawancara peneliti dengan pihak yang berwenang di Sekolah, pihak berwenang pada penelitian ini adalah, Kepala Sekolah, dan guru BP, yang telah memberikan informasinya mengenai kriteria dan alternatif penetapan beasiswa. Berikut struktur hirarki AHP sistem pendukung keputusan penentuan beasiswa

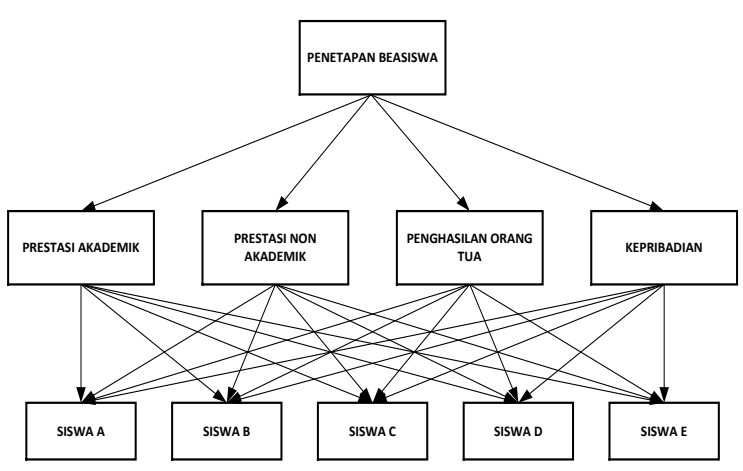

Sumber: Hasil analisis (2016)

Gambar 1. Struktur AHP Penetapan Beasiswa

\section{B. Hasil Pengolahan Data Analytica Hierarchy Process}

\section{Penentuan Bobot Antar Kriteria}

Setelah penginputan data perbandingan antar kriteria selesai dimasukan kedalam Expert Choice dan Microsoft Excel akan menghasilkan normalisasi matriks antar kriteria yang akan menentukan bobot setiap kriteria.

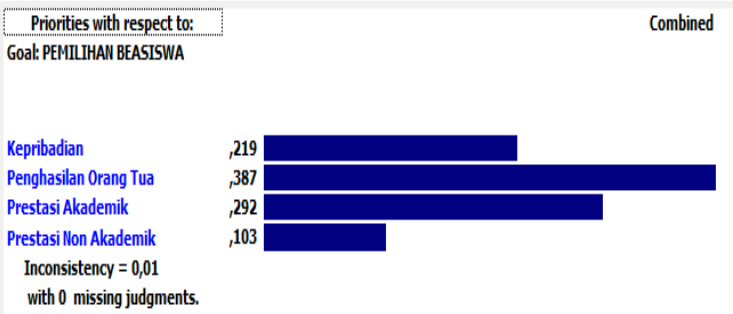

Sumber: Hasil pengolahan Expert Choice(2016)

Gambar 2. Grafik Normalisasi Matriks Antar Kriteria

Didalam Gambar 2., setiap kriteria mendapatkan nilai-nilai pembobotan. kriteria Prestasi Akademik 0,292 atau 29\%, kriteria Prestasi Non Akademik mendapatkan bobot 0,103 atau 10\%, kriteria Penghasilan Orang Tua mendapatkan bobot 0,386 atau 39\%, kriteria dan Kepribadian mendapatkan bobot 0,219 atau 22\%. Jika semua bobot ini dijumlahkan akan mendapatkan 1 atau $100 \%$.
Tabel IV.11 Grafik Normalisasi Matriks Antar Kriteria merupakan hasil dari Tabel 2. Pairwise Comparison Matriks Antar Kriteria. Hal ini dibuktikan dengan hitungan manual dibawah ini.

Tabel 2. Pairwise Comparison Matriks erdasarkan Antar Kriteria

\begin{tabular}{lllll} 
Kriteria & PA & PNA & POT & KP \\
\hline PA & 1 & 3,277 & 0,660 & 1,320 \\
\hline PNA & 0,305 & 1 & 0,272 & 0,530 \\
\hline POT & 1,516 & 3,680 & 1 & 1,585 \\
\hline KP & 0,758 & 1,888 & 0,63096 & 1 \\
\hline JML & 3,579 & 9,845 & 2,562 & 4,434 \\
\hline
\end{tabular}

Sumber: Hasil Analisis (2016)

Normalisasi dilakukan dengan cara membagi setiap entry pada Tabel 2. diatas dengan jumlah masing-masing kolom kriteria. Tabel 3 . berikut akan menjelaskan hasil perhitungan normalisasi

Tabel 3. Normalisasi Matriks Antar Kriteria

\begin{tabular}{llllllll}
\hline $\begin{array}{l}\text { Krite } \\
\text { ria }\end{array}$ & PA & $\begin{array}{l}\text { PN } \\
\text { A }\end{array}$ & $\begin{array}{l}\text { PO } \\
\text { T }\end{array}$ & KP & JML & $\begin{array}{l}\text { PRIORI } \\
\text { TAS }\end{array}$ & $\mathbf{\%}$ \\
\hline PA & 0,2 & 0,3 & 0,2 & 0,2 & 1,1 & $\mathbf{0 , 2 9 2}$ & 29 \\
& 79 & 33 & 57 & 98 & 67 & & $\%$ \\
\hline PNA & 0,0 & 0,1 & 0,1 & 0,1 & 0,4 & $\mathbf{0 , 1 0 3}$ & 10 \\
& 85 & 02 & 06 & 19 & 12 & & $\%$ \\
\hline POT & 0,4 & 0,3 & 0,3 & 0,3 & 1,5 & $\mathbf{0 , 3 8 6}$ & 39 \\
& 24 & 74 & 90 & 57 & 45 & & $\%$ \\
\hline KP & 0,2 & 0,1 & 0,2 & 0,2 & 0,8 & $\mathbf{0 , 2 1 9}$ & 22 \\
& 12 & 92 & 46 & 26 & 75 & & $\%$ \\
\hline JML & 1 & 1 & 1 & 1 & 4 & 1 & 100 \\
& & & & & & & $\%$ \\
\hline
\end{tabular}

Sumber: Hasil Analisis (2016)

Setelah tabel tersebut selesai dinormalisasi kemudian dilakukan penjumlahan untuk setiap barisnya. Kemudian jumlah setiap baris akan dibagi dengan jumlah kriteria yang kita miliki untuk menghasilkan bobot kriteria (Vector Priority).

Pada Tabel 7. dapat dilihat pada baris Tanggung Jawab jumlah 1,167 hasil ini didapat dari penjumlahan 0,279+0,333+0,257+0,298 = 1,167. Bobot kriteria (Vector Priority) 0,251 didapat dari hasil jumlah baris dibagi oleh total kriteria, 1,167/4 = 0,292.

Dari Tabel 3. akan didapatkan data sebagai berikut:

1. Bobot Kriteria (Vector Priority) Prestasi Akademik adalah 0,292

2. Bobot Kriteria (Vector Priority) Prestasi Non Akademik adalah 0,103

3. Bobot Kriteria (Vector Priority) penghasilan Orang Tua adalah 0,386

4. Bobot Kriteria (Vector Priority) Kepribadian adalah 0,219

Setelah mendapatkan bobot kriteria (Vector Priority) masing-masing kriteria. Lalu 
akan dilakukan pengecekan konsistensi data. Untuk menghitung Rasio Konsistensi (CR), dibutuhkan $\lambda \max$ (Eigen Maksimum) dan Indeks Konsistensi (CI).

1. Menentukan nilai Eigen maksimum $(\lambda \max )$ $\lambda \max$ diperoleh dan menjumlahkan seluruh hasil perkalian antara bobot kriteria (Vector Priority) dengan jumlah matriks Pairwise Comparison.

$\lambda \max =(3,579 \times 0,292)+$

$(9,845 \times 0,103)+(2,562 \times 0,386)+$

$(4,434 \times 0,219)$

$\lambda \max =1,045+1,014+0,988++0,971$

$$
=4,019
$$

2. Menghitung Indeks Konsistensi (CI)

$\mathrm{CI}=\frac{(\lambda \max -n)}{n-1}$

$\mathrm{n}=$ jumlah kriteria

$\mathrm{CI}=\frac{(4019-4)}{(4-1)}=0,006$

3. Menghitung Rasio Konsistensi (CR)

$\mathrm{CR}=\mathrm{CI} / \mathrm{RI}$, nilai RI untuk $\mathrm{n}=5$ adalah 1,12

(lihat pada tabel II.2 Daftar Indeks Random Konsistensi)

$\mathrm{CR}=\frac{\mathrm{CI}}{\mathrm{RI}}$

$\mathrm{CR}=\frac{0,006}{0,9}$

$\mathrm{CR}=0,007 \rightarrow 0,01$ (konsisten)

Perhitungan manual telah membuktikan

hasil Expert Choice pada Gambar 2. Grafik Normalisasi Matriks Antar Kriteria adalah benar.

\section{Penentuan Bobot Antar Alternatif} Berdasarkan Kriteria

a. Penentuan Bobot Antar Alternatif Berdasarkan Prestasi Akademik

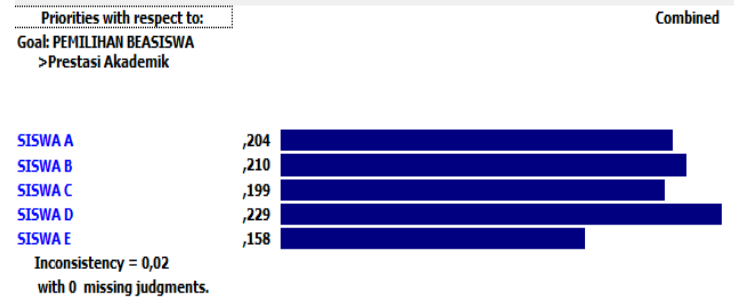

Sumber: Hasil pengolahan Expert Choice(2016) Gambar 3. Grafik Normalisasi Matriks Antar Alternatif Berdasarkan Prestasi Akademik

Didalam Gambar 3. setiap alternatif mendapatkan nilai-nilai pembobotan berdasarkan kriteria prestasi akademik setiap siswa. Siswa A mendapatkan bobot 0,203 atau sebesar 20\%, Siswa B mendapatkan bobot 0,211 atau sebesar 21\%, Siswa C mendapatkan bobot 0,198 atau sebesar 20\%, Siwa D mendapatkan bobot 0,229 atau sebesar $23 \%$ dan Siswa E mendapatkan bobot 0,159 atau sebesar 16\%. Jika semua bobot ini dijumlahkan akan mendapatkan 1 atau $100 \%$

Gambar 3. Grafik Normalisasi Matriks Antar Alternatif Berdasarkan Kriteria Prestasi Akademik merupakan hasil dari Tabel 4. Pairwise Comparison pemilihan beasiswa berdasarkan kriteria Prestasi Akademik. Hal ini dibuktikan dengan hitungan manual sebagai berikut ini.

Tabel 4. Tabel Pairwise Comparison Matriks pemilihan beasiswa berdasarkan Prestasi Akademik

\begin{tabular}{llllll}
\hline & $\begin{array}{l}\text { SISWA } \\
\text { A }\end{array}$ & $\begin{array}{l}\text { SISWA } \\
\text { B }\end{array}$ & $\begin{array}{l}\text { SISWA } \\
\text { C }\end{array}$ & $\begin{array}{l}\text { SISWA } \\
\text { D }\end{array}$ & $\begin{array}{l}\text { SISWA } \\
\text { E }\end{array}$ \\
\hline $\begin{array}{l}\text { SISWA } \\
\text { A }\end{array}$ & 1 & 1 & 0,758 & 0,758 & 1,888 \\
\hline $\begin{array}{l}\text { SISWA } \\
\text { B }\end{array}$ & 1 & 1 & 1,246 & 0,803 & 1,431 \\
\hline $\begin{array}{l}\text { SISWA } \\
\text { C }\end{array}$ & 1,320 & 0,803 & 1 & 0,803 & 1,217 \\
\hline $\begin{array}{l}\text { SISWA } \\
\text { D }\end{array}$ & 1,320 & 1,246 & 1,246 & 1 & 1 \\
\hline $\begin{array}{l}\text { SISWA } \\
\text { E }\end{array}$ & 0,530 & 0,699 & 0,822 & 1 & 1 \\
\hline JML & 5,170 & 4,747 & 5,071 & 4,363 & 6,536 \\
\hline Sumber & & & & & \\
\hline
\end{tabular}

Sumber: Hasil Analsis (2016)

Tabel 5. Tabel Normalisasi Pemilihan Beasiswa Berdasarkan Kriteria Prestasi Akademik

\begin{tabular}{lllllllll}
\hline & SISWA A & SISWA B & SISWA C & SISWA D & SISWA E & JML & PRTS & \% \\
\hline SISWA A & 0,193 & 0,211 & 0,149 & 0,174 & 0,289 & 1,016 & 0,203 & $20 \%$ \\
\hline SISWA B & 0,193 & 0,211 & 0,246 & 0,184 & 0,219 & 1,053 & 0,211 & $21 \%$ \\
\hline SISWA C & 0,255 & 0,169 & 0,197 & 0,184 & 0,186 & 0,992 & 0,198 & $20 \%$ \\
\hline SISWA D & 0,255 & 0,262 & 0,246 & 0,229 & 0,153 & 1,146 & 0,229 & $23 \%$ \\
\hline SISWA E & 0,102 & 0,147 & 0,162 & 0,229 & 0,153 & 0,794 & 0,159 & $16 \%$ \\
\hline JML & 1 & 1 & 1 & 1 & 1 & 5 & 1 & $100 \%$ \\
\hline
\end{tabular}

Sumber: Hasil Analsis (2016) 
Dari Tabel 5. akan didapatkan data sebagai berikut:

1. Bobot Alternatif (Vector Priority) Siswa A adalah 0,203

2. Bobot Alternatif (Vector Priority) Siswa B adalah 0,211

3. Bobot Alternatif (Vector Priority) Siswa C adalah 0,198

4. Bobot Alternatif (Vector Priority) Siswa D adalah 0,229

5. Bobot Alternatif (Vector Priority) Siswa E adalah 0,159

Perhitungan Konsistensi:

1. Menghitung nilai Eigen maksimum ( $\lambda$ max $)$

$\lambda \max =((5,170 \times 0,203)$

$$
\begin{aligned}
& +(4,747 \times 0,211) \\
& +(5,071 \times 0,198) \\
& +(4,363 \times 0,229) \\
& +(6,536 \times 0,159)
\end{aligned}
$$

$\lambda \max =5,093$

2. Menghitung Indeks Konsistensi (CI)

$\mathrm{CI}=\frac{(\lambda \max -n)}{n-1}$

$\mathrm{n}=$ jumlah kriteria

$\mathrm{CI}=\frac{(5,093-5)}{5-1}$

$\mathrm{CI}=\frac{0,093}{4}=0,023$

3. Menghitung Rasio Konsistensi (CR)

$\mathrm{CR}=\mathrm{CI} / \mathrm{RI}$, nilai RI untuk 3 adalah 0,58 (lihat pada tabel II.2 Daftar Indeks Random Konsistensi)

$\mathrm{CR}=\frac{\mathrm{CI}}{\mathrm{RI}}$

$\mathrm{CR}=\frac{0,023}{1,12}$

$\mathrm{CR}=0,02 \rightarrow 0,02$ (konsisten)

Perhitungan manual telah membuktikan

hasil Expert Choice pada Gambar 3. Grafik Normalisasi Matriks Antar Alternatif Berdasarkan Kriteria Prestasi Akademik adalah benar.

b. Penentuan Bobot Antar Alternatif Berdasarkan Kriteria Prestasi Non Akademik

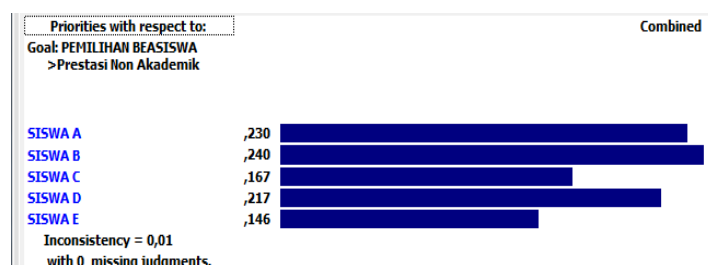

Sumber: Hasil pengolahan Expert Choice(2016) Gambar 4. Grafik Normalisasi Matriks Antar Alternatif Berdasarkan Kriteria Prestasi Non Akademik

Didalam Gambar 4. setiap alternatif mendapatkan nilai-nilai pembobotan berdasarkan kriteria prestasi non akademik setiap siswa. Siswa A mendapatkan bobot 0,230 atau sebesar 23\%, Siswa B mendapatkan bobot 0,240 atau sebesar 24\%, Siswa C mendapatkan bobot 0,166 atau sebesar 17\%, Siswa D mendapatkan bobot 0,217 atau sebesar 22\% dan Siswa E mendapatkan bobot 0,146 atau sebesar 15\% Jika semua bobot ini dijumlahkan akan mendapatkan 1 atau $100 \%$.

Gambar 4. Grafik Normalisasi Matriks Antar Alternatif Berdasarkan Kriteria Prestasi Non Akademik merupakan hasil dari Tabel 6. Pairwise Comparison Pemilihan Beasiswa Berdasarkan Kriteria Prestasi Non Akademik. Hal ini dibuktikan dengan hitungan manual sebagai berikut ini.

Tabel 6. Tabel Pairwise Comparison Matriks Pemilihan BeasiswaBerdasarkan Kriteria Prestasi Non Akademik

\begin{tabular}{llllll}
\hline & $\begin{array}{l}\text { SISWA } \\
\text { A }\end{array}$ & $\begin{array}{l}\text { SISWA } \\
\text { B }\end{array}$ & $\begin{array}{l}\text { SISWA } \\
\text { C }\end{array}$ & $\begin{array}{l}\text { SISWA } \\
\text { D }\end{array}$ & $\begin{array}{l}\text { SISWA } \\
\text { E }\end{array}$ \\
\hline $\begin{array}{l}\text { SISWA } \\
\text { A }\end{array}$ & 1 & 1,059 & 1,644 & 0,923 & 1,431 \\
\hline $\begin{array}{l}\text { SISWA } \\
\text { B }\end{array}$ & 0,944 & 1 & 1 & 1,320 & 2,096 \\
\hline $\begin{array}{l}\text { SISWA } \\
\text { C }\end{array}$ & 0,608 & 1,000 & 1 & 0,660 & 1,059 \\
\hline $\begin{array}{l}\text { SISWA } \\
\text { D }\end{array}$ & 1,084 & 0,758 & 1,516 & 1 & 1,351 \\
\hline $\begin{array}{l}\text { SISWA } \\
\text { E }\end{array}$ & 0,699 & 0,477 & 0,944 & 0,740 & 1 \\
\hline JML & 4,335 & 4,294 & 6,104 & 4,642 & 6,937 \\
\hline
\end{tabular}

Sumber: Hasil Analsis (2016)

Tabel 7. Tabel Normalisasi Pemilihan beasiswa Berdasarkan Kriteria Prestasi Non Akademik

\begin{tabular}{lllllllll}
\hline & SISWA A & SISWA B & SISWA C & SISWA D & SISWA E & JML & PRTS & \% \\
\hline SISWA A & 0,231 & 0,247 & 0,269 & 0,199 & 0,206 & 1,152 & 0,230 & $23 \%$ \\
\hline SISWA B & 0,218 & 0,233 & 0,164 & 0,284 & 0,302 & 1,201 & 0,240 & $24 \%$ \\
\hline SISWA C & 0,140 & 0,233 & 0,164 & 0,142 & 0,153 & 0,832 & 0,166 & $17 \%$ \\
\hline SISWA D & 0,250 & 0,176 & 0,248 & 0,215 & 0,195 & 1,085 & 0,217 & $22 \%$ \\
\hline SISWA E & 0,161 & 0,111 & 0,155 & 0,159 & 0,144 & 0,731 & 0,146 & $15 \%$ \\
\hline JML & 1 & 1 & 1 & 1 & 1 & 5 & 1 & $100 \%$ \\
\hline
\end{tabular}

Sumber: Hasil Analsis (2016) 
Dari Tabel 7. akan didapatkan data sebagai berikut:

1. Bobot Alternatif (Vector Priority) Siswa A adalah 0,230

2 Bobot Alternatif (Vector Priority) Siswa B adalah 0,240

3 Bobot Alternatif (Vector Priority) Siswa C adalah 0,166

4 Bobot Alternatif (Vector Priority) Siswa D adalah 0,217

5 Bobot Alternatif (Vector Priority) Siswa E adalah 0,146

Perhitungan Konsistensi:

1. Menghitung nilai Eigen maksimum $(\lambda \max )$

$\lambda \max =((4,335 \times 0,230)$

$$
\begin{aligned}
& +(4,294 \times 0,240) \\
& +(6,104 \times 0,166) \\
& +(4,642 \times 0,217) \\
& +(6,937 \times 0,146))
\end{aligned}
$$

$\lambda \max =5,066$

$2 \quad$ Menghitung Indeks Konsistensi (CI)

$\mathrm{CI}=\frac{(\lambda \max -n)}{n-1}$

$\mathrm{n} \quad=$ jumlah kriteria

$\mathrm{CI}=\frac{(5,066-5)}{5-1}$

$\mathrm{CI}=\frac{0,066}{4}=0,017$

3 Menghitung Rasio Konsistensi (CR)

$\mathrm{CR}=\mathrm{CI} / \mathrm{RI}$, nilai RI untuk 3 adalah 0,58

(lihat pada tabel II.2 Daftar Indeks Random Konsistensi)

$\mathrm{CR}=\frac{\mathrm{CI}}{\mathrm{RI}}$

$\mathrm{CR}=\frac{0,017}{1,12}$

$\mathrm{CR}=0,015 \rightarrow 0,01$ (konsisten)

Perhitungan manual telah membuktikan

hasil Expert Choice pada Gambar 4. Grafik Normalisasi Matriks Antar Alternatif Berdasarkan Kriteria Prestasi Non Akademik.

c. Penentuan Bobot Antar Alternatif Berdasarkan Kriteria Penghasilan Orang Tua

Priorities with respect to: aat: PEMILIHAN BEASISWA (n)

SISWAA

SISWA

SISWAC
SISWAD

SISWAE

Inconsistency $=0,01$

, 220

, 128

with 0 missing

Sumber: Hasil pengolahan Expert Choice(2016)

Gambar 6. Grafik Normalisasi Matriks Antar

Alternatif Berdasarkan Kriteria Penghasilan Orang Tua

Didalam Gambar 6. setiap alternatif mendapatkan nilai-nilai pembobotan berdasarkan kriteria Penghasilan Orang Tua setiap siswa. Siswa A mendapatkan bobot 0,210 atau sebesar 21\%, Siswa B mendapatkan bobot 0,220 atau sebesar 22\%, Siswa C mendapatkan bobot 0,143 atau sebesar 14\%, Siswa D mendapatkan bobot 0,129 atau sebesar 13\% dan Siswa E mendapatkan bobot 0,298 atau sebesar $30 \%$ jika semua bobot ini dijumlahkan akan mendapatkan 1 atau 100\%.

Gambar 6. Grafik Normalisasi Matriks Antar Alternatif Berdasarkan Kriteria Penghasilan Orang Tua merupakan hasil dari Tabel 4. Pairwise Comparison Penilaian Kineja Karyawan Berdasarkan Kriteria Kemampuan. Hal ini dibuktikan dengan hitungan manual sebagai berikut ini.

Tabel 8. Pairwise Comparison Matriks Pemilihan Beasiswa Berdasarkan Kriteria Penghasilan Orang Tua

\begin{tabular}{llllll}
\hline & $\begin{array}{l}\text { SISWA } \\
\text { A }\end{array}$ & $\begin{array}{l}\text { SISWA } \\
\text { B }\end{array}$ & $\begin{array}{l}\text { SISWA } \\
\text { C }\end{array}$ & $\begin{array}{l}\text { SISWA } \\
\text { D }\end{array}$ & $\begin{array}{l}\text { SISWA } \\
\text { E }\end{array}$ \\
\hline $\begin{array}{l}\text { SISWA } \\
\text { A }\end{array}$ & 1 & 1,084 & 1,516 & 1,741 & 0,561 \\
\hline $\begin{array}{l}\text { SISWA } \\
\text { B }\end{array}$ & 0,923 & 1 & 1,351 & 1,585 & 1,000 \\
\hline $\begin{array}{l}\text { SISWA } \\
\text { C }\end{array}$ & 0,660 & 0,740 & 1 & 1,084 & 0,4610 \\
SISWA & 0,574 & 0,631 & 0,923 & 1 & 0,4251 \\
D & & & & & 7 \\
\hline $\begin{array}{l}\text { SISWA } \\
\text { E }\end{array}$ & 1,783 & 1,000 & 2,169 & 2,352 & 1 \\
\hline JML & 4,940 & 4,455 & 6,959 & 7,762 & 3,447 \\
\hline
\end{tabular}

Sumber: Hasil Analsis (2016)

Tabel 9. Tabel Normalisasi Pemilihan Beasiswa Berdasarkan Kriteria Penghasilan Orang Tua

\begin{tabular}{lllllllll}
\hline & SISWA A & SISWA B & SISWA C & SISWA D & SISWA E & JML & PRTS & \% \\
\hline SISWA A & 0,202 & 0,243 & 0,218 & 0,224 & 0,163 & 1,051 & 0,210 & $21 \%$ \\
\hline SISWA B & 0,187 & 0,224 & 0,194 & 0,204 & 0,290 & 1,100 & 0,220 & $22 \%$ \\
\hline SISWA C & 0,134 & 0,166 & 0,144 & 0,140 & 0,134 & 0,717 & 0,143 & $14 \%$ \\
\hline SISWA D & 0,116 & 0,142 & 0,133 & 0,129 & 0,123 & 0,643 & 0,129 & $13 \%$ \\
\hline SISWA E & 0,361 & 0,224 & 0,312 & 0,303 & 0,290 & 1,490 & 0,298 & $30 \%$ \\
\hline JML & 1 & 1 & 1 & 1 & 1 & 5 & 1 & $100 \%$ \\
\hline
\end{tabular}

Sumber: Hasil Analsis (2016) 
Dari Tabel 9. akan didapatkan data sebagai berikut:

1. Bobot Alternatif (Vector Priority) Siswa A adalah 0,210

2. Bobot Alternatif (Vector Priority) Siswa B adalah 0,220

3. Bobot Alternatif (Vector Priority) Siswa C adalah 0,143

4. Bobot Alternatif (Vector Priority) Siswa D adalah 0,129

5. Bobot Alternatif (Vector Priority) Siswa E adalah 0,298

Perhitungan Konsistensi:

1. Menghitung nilai Eigen maksimum ( $\lambda$ max)

$\lambda \max =((4,940 \times 0,210)$

$$
\begin{aligned}
& +(4,455 \times 0,220) \\
& +(6,959 \times 0,143) \\
& +(7,762 \times 0,129) \\
& +(3,447 \times 0,298))
\end{aligned}
$$

$\lambda \max =5,04$

$2 \quad$ Menghitung Indeks Konsistensi (CI)

$\mathrm{CI}=\frac{(\lambda \max -n)}{n-1}$

$\mathrm{n} \quad=$ jumlah kriteria

$\mathrm{CI}=\frac{(5,04-5)}{5-1}$

$\mathrm{CI}=\frac{0,04}{4}=0,01$

3 Menghitung Rasio Konsistensi (CR)

$\mathrm{CR}=\mathrm{CI} / \mathrm{RI}$, nilai RI untuk 3 adalah 0,58

(lihat pada tabel II.2 Daftar Indeks Random Konsistensi)

$\mathrm{CR}=\frac{\mathrm{CI}}{\mathrm{RI}}$

$\mathrm{CR}=\frac{0,01}{1,12}$

$\mathrm{CR}=0,01 \rightarrow 0,01$ (konsisten)

Perhitungan manual telah membuktikan

hasil Expert Choice pada Gambar 6. Grafik Normalisasi Matriks Antar Alternatif Berdasarkan Kriteria Penghasilan Orang Tua adalah benar.

d. Penentuan Bobot Antar Alternatif Berdasarkan Kriteria Kepribadian

8)
Priorities with respect to:

Goal: PEMILIHAN BEASISWA

$>$ Kepribadian

SISWAA

SISWA B

SISWAC

SISWA D

Inconsistency $=0,03$

with 0 missing judgments.

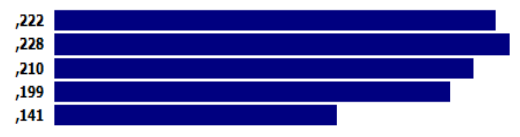

Sumber: Hasil pengolahan Expert Choice(2016) Gambar 7. Grafik Normalisasi Matriks Antar Alternatif Berdasarkan Kriteria Kepribadian

Didalam Gambar 7. setiap alternatif mendapatkan nilai-nilai pembobotan berdasarkan kriteria Kepribadian setiap siswa. Siswa A mendapatkan bobot 0,221 atau sebesar $22 \%$, Siswa B mendapatkan bobot 0,227 atau sebesar 23\% dan Siswa C mendapatkan bobot 0,210 atau sebesar 21\%, Siswa D mendapatkan bobot 0,200 atau sebesar $20 \%$ dan Siswa E mendapatkan bobot 0,141 atau sebesar 14\% Jika semua bobot ini dijumlahkan akan mendapatkan 1 atau $100 \%$.

Gambar 7. Grafik Normalisasi Matriks Antar Alternatif Berdasarkan Kriteria Kepribadian merupakan hasil dari tabel IV.5 Pairwise Comparison Penilaian Kineja Karyawan Berdasarkan Kriteria Kerjasama. Hal ini dibuktikan dengan hitungan manual sebagai berikut ini.

Tabel 10. Pairwise Comparison Matriks Pemilihan BeasiswaBerdasarkan Kriteria Kepribadian

\begin{tabular}{llllll} 
PA & $\begin{array}{l}\text { SISWA } \\
\text { A }\end{array}$ & $\begin{array}{l}\text { SISWA } \\
\text { B }\end{array}$ & $\begin{array}{l}\text { SISWA } \\
\text { C }\end{array}$ & $\begin{array}{l}\text { SISWA } \\
\text { D }\end{array}$ & $\begin{array}{l}\text { SISWA } \\
\text { E }\end{array}$ \\
\hline $\begin{array}{l}\text { SISWA } \\
\text { A }\end{array}$ & 1 & 1,431 & 0,758 & 1 & 1,644 \\
\hline $\begin{array}{l}\text { SISWA } \\
\text { B }\end{array}$ & 0,699 & 1 & 1,246 & 1,783 & 1,217 \\
\hline $\begin{array}{l}\text { SISWA } \\
\text { C }\end{array}$ & 1,320 & 0,803 & 1 & 0,803 & 1,644 \\
\hline $\begin{array}{l}\text { SISWA } \\
\text { D }\end{array}$ & 1 & 0,561 & 1,246 & 1 & 1,516 \\
\hline $\begin{array}{l}\text { SISWA } \\
\text { E }\end{array}$ & 0,608 & 0,822 & 0,608 & 0,660 & 1 \\
\hline JML & 4,627 & 4,616 & 4,858 & 5,245 & 7,021 \\
\hline
\end{tabular}

Sumber: Hasil Analsis (2016)

Tabel 11. Tabel Normalisasi Pemilihan Beasiswa Berdasarkan Kriteria Kepribadian

\begin{tabular}{lllllllll}
\hline SKP & SISWA A & SISWA B & SISWA C & SISWA D & SISWA E & JML & PRTS & \% \\
\hline SISWA A & 0,216 & 0,310 & 0,156 & 0,191 & 0,234 & 1,107 & 0,221 & $22 \%$ \\
\hline SISWA B & 0,151 & 0,217 & 0,256 & 0,340 & 0,173 & 1,137 & 0,227 \\
\hline SISWA C & 0,285 & 0,174 & 0,206 & 0,153 & 0,234 & 1,052 & 0,210 & $21 \%$ \\
\hline SISWA D & 0,216 & 0,121 & 0,256 & 0,191 & 0,216 & 1,001 & 0,200 & $20 \%$ \\
\hline SISWA E & 0,131 & 0,178 & 0,125 & 0,126 & 0,142 & 0,703 & 0,141 & $14 \%$ \\
\hline JML & 1 & 1 & 1 & 1 & 1 & 5 & 1 & $100 \%$
\end{tabular}

Sumber: Hasil Analsis (2016) 
Dari Tabel 11. akan didapatkan data sebagai berikut:

1. Bobot Alternatif (Vector Priority) Siswa A adalah 0,221

2. Bobot Alternatif (Vector Priority) Siswa B adalah 0,227

3. Bobot Alternatif (Vector Priority) Siswa C adalah 0,210

4. Bobot Alternatif (Vector Priority) Siswa D adalah 0,200

5. Bobot Alternatif (Vector Priority) Siswa E adalah 0,141

Perhitungan Konsistensi:

1. Menghitung nilai Eigen maksimum ( $\lambda$ max $)$ $\lambda \max =((4,627 \times 0,221)$

$$
\begin{aligned}
& +(4,616 \times 0,227) \\
& +(4,858 \times 0,210) \\
& +.(5,245 \times 0.20 .0 .0 .0 .(10) \\
& +(7,021 \times 0,141))
\end{aligned}
$$

$\lambda \max =5,133$

2. Menghitung Indeks Konsistensi (CI)

$$
\begin{aligned}
& \mathrm{CI}=\frac{(\lambda \max -n)}{n-1} \\
& \mathrm{n}=\text { jumlah kriteria }
\end{aligned}
$$

$$
\begin{aligned}
& C I=\frac{(5,133-5)}{5-1} \\
& C I=\frac{0,133}{4}=0,033
\end{aligned}
$$

3. Menghitung Rasio Konsistensi (CR)

$\mathrm{CR}=\mathrm{CI} / \mathrm{RI}$, nilai RI untuk 3 adalah 0,58 (lihat pada tabel II.2 Daftar Indeks Random Konsistensi)

$\mathrm{CR}=\frac{\mathrm{CI}}{\mathrm{RI}}$

$\mathrm{CR}=\frac{0,03}{1,12}$

$\mathrm{CR}=0,03 \rightarrow 0,03$ (konsisten)

Perhitungan manual telah membuktikan hasil Expert Choice pada Gambar 7. Grafik Normalisasi Matriks Antar Alternatif

\begin{tabular}{|c|c|c|}
\hline Percen... & & 21,2 \\
\hline \multirow{3}{*}{ SISWAA } & Prestasi Akademik (L: 0,292) & 059 \\
\hline & Prestasi Non Akademik (L: 0,103) & .024 \\
\hline & Penghasilan Orang Tua (L: 0,387$)$ & 081 \\
\hline \multirow[t]{2}{*}{ Percen... } & & 22,1 \\
\hline & Prestasi Akademik (L: 0,292) & .061 \\
\hline \multirow{2}{*}{ SISWA B } & Prestasi Non Ákademik (L: 0,103) & .025 \\
\hline & Kepribadian (L: 0,219) & 050 \\
\hline \multirow[t]{2}{*}{ Percen... } & & 17,6 \\
\hline & Prestasi Akademik (L: 0,292) & .058 \\
\hline \multirow{3}{*}{ SISWAC } & Prestasi Non Akademik (L: 0,103) & .017 \\
\hline & Penghasilan Drang Tua (L: 0,387$)$ & .055 \\
\hline & Kepribadian (L: 0,219) & .046 \\
\hline SISWA D & Kepribadian (L: 0,219) & .044 \\
\hline \multirow[t]{2}{*}{ Percen... } & & 20,8 \\
\hline & Prestasi Ákademik (L: 0,292) & .046 \\
\hline \multirow{3}{*}{ SISW/AE } & Prestasi Non Akademik (L: 0,103) & .015 \\
\hline & Penghasilan Orang Tua (L: 0,387) & .116 \\
\hline & Kepribadian (L: 0,219) & 031 \\
\hline
\end{tabular}
Berdasarkan Kriteria Kepribadian adalah benar.

\subsection{Hasil Pengolahan Analytical Hierarchy Process}

Setelah mendapatkan nilai masing-masing dari setiap pembobotan kriteria dan setiap alternatif berdasarkan kriteria, kemudian diperoleh hasil seperti Gambar 8. berikut ini:

Sumber: Hasil pengolahan Expert Choice(2016)

Gambar 8. Hasil Perhitungan Penilaian Akhir

Pada Gambar 8 baris berwarna kuning merupakan hasil penjumlahan dari setiap aggregate/prty. Hasil penjumlahan ini merupakan hasil akhir dari penilaian kinerja karyawan. Siswa A mendapatkan nilai $21.2 \%$, Siswa B mendapatkan nilai $22.1 \%$, dan Siswa C mendapatkan nilai $17.6 \%$, Siswa D mendapatkan nilai $18,3 \%$ dan Siswa E mendapatkan nilai $20,8 \%$.

\section{Perhitungan Hasil Pengolahan Data Analytical Hierarchy Process}

Perhitungan terakhir yang dilakukan untuk pemilihan beasiswa adalah menghitung nilai aggregate masing-masing siswa yang 
dijadikan alternatif. Nilai aggregate diperoleh dengan cara mengalikan nilai bobot setiap

Tabel 12. Tabel Hasil Penilaian Akhir

\begin{tabular}{|c|c|c|c|c|}
\hline $\begin{array}{l}\text { ltern } \\
\text { atif }\end{array}$ & $\begin{array}{l}\text { Krite } \\
\text { ria }\end{array}$ & $\begin{array}{l}\text { Bobot } \\
\text { Perbandi } \\
\text { ngan } \\
\text { Faktor } \\
\text { Antar } \\
\text { Kriteria }\end{array}$ & $\begin{array}{l}\text { Bobot } \\
\text { Perbandi } \\
\text { ngan } \\
\text { Faktor } \\
\text { Antar } \\
\text { Alternati } \\
\text { f }\end{array}$ & $\begin{array}{l}\text { Aggre } \\
\text { gate }\end{array}$ \\
\hline \multirow{5}{*}{$\begin{array}{l}\text { SISW } \\
\text { A A }\end{array}$} & PA & 0,292 & 0,203 & 0,059 \\
\hline & PNA & 0,103 & 0,230 & 0,024 \\
\hline & POT & 0,386 & 0,210 & 0,081 \\
\hline & KPD & 0,219 & 0,221 & 0,048 \\
\hline & \multicolumn{3}{|c|}{ Persentase Siswa A } & $21,3 \%$ \\
\hline \multirow{5}{*}{$\begin{array}{l}\text { SISW } \\
\text { A B } \\
\end{array}$} & PA & 0,292 & 0,211 & 0,061 \\
\hline & PNA & 0,103 & 0,240 & 0,025 \\
\hline & POT & 0,386 & 0,220 & 0,085 \\
\hline & KPD & 0,219 & 0,227 & 0,050 \\
\hline & \multicolumn{3}{|c|}{ Persentase Siswa B } & $22,1 \%$ \\
\hline \multirow{5}{*}{$\begin{array}{l}\text { SISW } \\
\text { A C }\end{array}$} & PA & 0,292 & 0,198 & 0,058 \\
\hline & PNA & 0,103 & 0,166 & 0,017 \\
\hline & POT & 0,386 & 0,143 & 0,055 \\
\hline & KPD & 0,219 & 0,210 & 0,046 \\
\hline & \multicolumn{3}{|c|}{ Persentase Siswa C } & $17,6 \%$ \\
\hline \multirow{5}{*}{$\begin{array}{l}\text { SISW } \\
\text { A D }\end{array}$} & PA & 0,292 & 0,229 & 0,067 \\
\hline & PNA & 0,103 & 0,217 & 0,022 \\
\hline & POT & 0,386 & 0,129 & 0,050 \\
\hline & KPD & 0,219 & 0,200 & 0,044 \\
\hline & \multicolumn{3}{|c|}{ Persentase Siswa D } & $18,3 \%$ \\
\hline \multirow{5}{*}{ A E } & PA & 0,292 & 0,159 & 0,046 \\
\hline & PNA & 0,103 & 0,146 & 0,015 \\
\hline & POT & 0,386 & 0,298 & 0,115 \\
\hline & KPD & 0,219 & 0,141 & 0,031 \\
\hline & \multicolumn{3}{|c|}{ Persentase Siswa E } & $20,7 \%$ \\
\hline
\end{tabular}

Sumber: Hasil Analsis (2016)

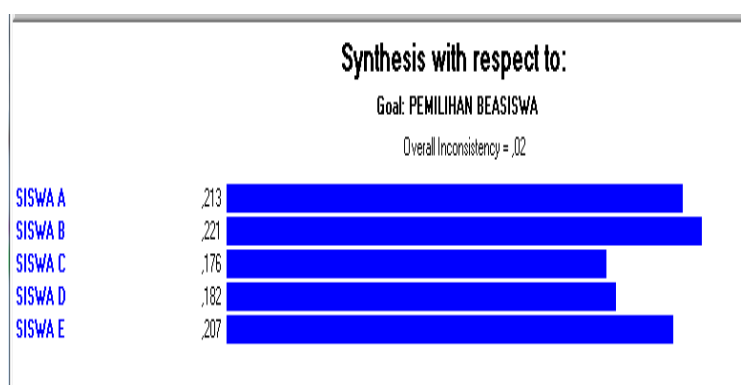

Sumber: Hasil pengolahan Expert Choice(2016)

Gambar 9. Hasil Synthesis With Respect kriteria dengan nilai bobot setiap alternatif siswa dengan kriteria yang sama.

Gambar 9. merupakan hasil dari perhitungan keseluruhan Analytical Hierarchy Process untuk pemilihan beasiswa dengan menggunakan aplikasi Expert Choice dalam bentuk grafik. Hal ini menunjukkan bahwa Siswa B lebih unggul dari alternatif lainnya dalam pemilihan beasiswa. Hasil perhitungan ini menunjukkan juga bahwa Siswa B lebih memenuhi kriteria yang telah ditentukan sebelumnya oleh Kepala Sekolah, Guru BP, Wakil KepSek Bidang Kurikulum, Wali Kelas 1, dan Wali Kelas 2.

\section{KESIMPULAN}

Berdasarkan perhitungan Analytical Hierarchy Process (AHP), diperoleh prioritas kriteria dalam penilaian terhadap Pemilihan Beasiswa. Dimana Prestasi Akademik, Prestasi Non Akademik, Penghasilan Orang Tua, dan Kepribadian menjadi tolak ukur dalam melakukan pemilihan beasiswa. Hasil akhir yang didapat dari pemilihan beasiswa oleh lima orang ahli bahwa Siswa B lebih unggul 0,221 $(22,1 \%)$ sedangkan Siswa A 0,213 (21,3\%), Siswa E 0,207 $(20,7 \%)$, Siswa D 0,182 (18,2\%) dan Siswa C $0,176(17,6 \%)$.

\section{REFERENSI}

Hardi, R. (2014). Pemodelan Sistem Pendukung Keputusan Dengan Fuzzy AHP Dalam Penentuan Penerimaan Beasiswa. Simposium Nasional RAPI XII (pp. E177E183). Surakarta: Universitas Muhammadiyah Surakarta.

Kirom, D. N., Bilfaqih, Y., \& Effendie, R. (2012). Sistem Informasi Manajemen Beasiswa ITS Berbasis Sistem Pendukung Keputusan Menggunakan Analytical Hierarchy Process. Jurnal Teknik ITS, A-154 - A-159.

Rizal. (2013). Sistem Pendukung Keputusan Seleksi Calon Penerima Beasiswa Pada Universitas Malikussaleh. JT-FTI, 113-124.

Supriyono. (n.d.). Sistem Penunjang Keputusan (SPK) Pemilihan Sepeda Motor Menggunakan AHP. Jurnal Simetris, 55-58.

Yulianti, E., \& Damayanti, R. (2015, Oktober 2). Sistem Pendukung Keputusan Untuk Menentukan Penerimaan Beasiswa Bagi Siswa SMA N 9 Padang Dengan Menggunakan Metode AHP. Jurnal TEKNOIF, 21-28. 


\section{BIODATA PENULIS}

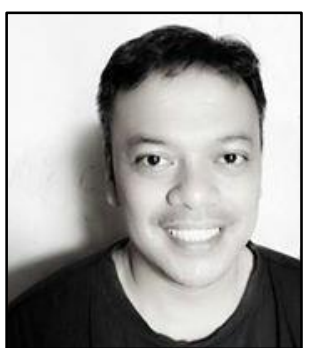

Frieyadie, seorang dosen profesional yang memiliki jenjang pendidikan Magister Ilmu Komputer, memiliki jabatan fungsional akademik Lektor dan memiliki Sertifikasi Dosen (2015). Memiliki sertifikat sebagai Asesor Kompetensi dibidang TIK Pemrograman Komputer. Sebagai penyusun Standar Kompetensi Lulusan Bidang Web Desain dan Programming. Telah menulis beberapa buku yang diterbitkan di Elex Media Komputindo dan Andi Publisher. Interest Research pada bidang Sistem Informasi, dan Sistem Penunjang
Keputusan. Penelitian Terakhir: 1) Frieyadie \& Titin Kristiana. Konferensi Nasional Ilmu Pengetahuan dan Teknologi Ke-2 Tahun 2016 "Peran Digital Megatrends Dalam Berbagai Aspek Keilmuan (2016)" dengan judul "RANCANG BANGUN SISTEM INFORMASI ADMINISTRASI TEMPAT PEMAKAMAN UMUM (TPU)", 2) Frieyadie. Jurnal Pilar Nusa Mandiri Vol 12, No 1 Maret 2016, dengan judul "PENERAPAN METODE SIMPLE ADDITIVE WEIGHT (SAW) DALAM SISTEM PENDUKUNG KEPUTUSAN PROMOSI KENAIKAN JABATAN, 3) Frieyadie. Jurnal Sistem Informasi STMIK Antar Bangsa.Vol IV No. 2 Agustus 2015, dengan judul "Penerapan Rapid Application Development Model Pada Perancangan dan Kajian Sistem Informasi Penjalan Berbasis Web" 